\title{
DEKONSTRUKSI CERITA ASAL USUL TARI TRADISIONAL MINANGKABAU MENJADI KARYA SASTRA BERBASIS KEBUDAYAAN LOKAL
}

\author{
Yosi Wulandari \\ PBSI FKIP Universitas Ahmad Dahlan \\ yosi.wulandari@pbsi.uad.ac.id
}

\begin{abstract}
Abstrak
Perkembangan zaman merupakan sesuatu yang tidak dapat dihindari bagi negara berkembang seperti Indonesia. Kehadiran MEA di Indonesia pun menyibukan berbagai pihak menyiapkan diri untuk siap berdaya saing di tingkat ASEAN. Akan tetapi, di lain hal pemerintah pun resah dengan budaya literasi masyarakat kita yang sangat rendah. Keberadaan perpustakaan dan program pemerintah yang lain tidak menunjukan hasil yang optimal. Oleh karena itu, perlu menumbuhkan budaya literasi dengan ide kreatif sehingga kebudayaan dapat dikembangkan.

Memanfaatkan kebudayaan yang dimiliki Indonesia adalah salah satu cara untuk tetap aktif membaca dan menulis. Banyak hal yang dapat dikembangkan sehingga pendidik ataupun peserta didik dapat memanfaatkan hal ini sebagai upaya menjaga budaya literasi. Minangkabau sebagai suku masyarakat di Sumatera Barat memiliki kekayaan budaya, misalnya tari-tari tradisional. Akan tetapi, tidak semua orang memahami filosofi tarian tersebut. Bagi orang Minangkabau, segala hal yang disampaikan meskipun lewat tari dan musik memiliki makna dan cerita. Hal tersebutlah yang penting untuk dijaga dan dilestarikan lewat budaya literasi sehingga kearifan lokal budaya Indonesia dapat diperkenalkan kepada generasi bangsa kelak.

Potensi tersebut dapat digunakan sebagai salah satu upaya meningkatkan budaya literasi, yaitu membaca kebudayaan yang dimiliki dan dikembangkan lewat menulis karya sastra. Teori dekonstruksi merupakan sebuah tawaran pembacaan yang mendalam terhadap teks kebudayaan. Kemudian digunakan sebagai bahan proses kreatif penciptaan karya sastra yang memiliki konsep pendidikan karakter dan berbasis kebudayaan lokal. Kata kunci: dekonstruksi, literasi, cerita tari tradisional, karya sastra, budaya lokal
\end{abstract}

\begin{abstract}
The times is something that can not be avoided for developing countries like Indonesia. MEA's presence in Indonesia was busily engaged in various parties prepare themselves to be ready to competitiveness in the ASEAN level. However, on the other hand the government is troubled by the literate culture of our society is very low. The existence of libraries and other government programs do not show optimal results. Therefore, the need to foster a culture of literacy with creative ideas so that culture can be developed.

Utilizing owned Indonesian culture is one way to stay active reading and writing. Many things can be developed so that teachers or learners can use this as an effort to maintain a culture of literacy. Minangkabau as tribal people in West Sumatra has a rich culture, such as traditional dances. However, not everyone understands the philosophy of the dance. For the Minangkabau, everything delivered although through dance and music has a meaning and a story. This is exactly what is important to be maintained and
\end{abstract}


preserved through cultural literacy so that local knowledge of Indonesian culture can be introduced to the nation's future generations.

This potential can be used as an effort to improve cultural literacy, reading culture that is owned and developed through writing literature. The theory of deconstruction was a bid profound reading of the text culture. Later it was used as a creative process of creation of literary works which have the concept of character education and culture-based local.

Keywords: deconstruction, literacy, story traditional dance, literature, local culture

\section{Pendahuluan}

\subsection{Latar Belakang}

Keberadaan karya sastra sebagai dokumentasi kebudayaan merupakan hal penting yang dapat dimanfaatkan lebih baik lagi. Sudah seharusnya perhatian terhadap hal ini bukan menjadi wacana atau materi kuliah semata. Oleh karena itu, perlu sebuah gagasan kreatif dan produktivitas yang lebih baik untuk meningkatkan budaya literasi masyarakat Indonesia.

Persaingan global dan kemajuan teknologi telah menyibukan masyarakat Indonesia dengan berbagai hal untuk meningkatkan kemampuan ekonomi, pengetahuan, dan teknologi. Hal tersebut merupakan sesuatu yang tidak dapat dihindari bagi negara berkembang seperti Indonesia. Kehadiran MEA di Indonesia pun menyibukan berbagai pihak menyiapkan diri untuk siap berdaya saing di tingkat ASEAN. Akan tetapi, di lain hal pemerintah pun resah dengan budaya literasi masyarakat kita yang sangat rendah. Keberadaan perpustakaan dan program pemerintah yang lain tidak menunjukan hasil yang optimal.

Selain itu, kondisi kebudayaan yang menjadi ciri khas Indonesia pun berada dalam kondisi yang merasahkan. Tidak semua masyarakat Indonesia memiliki pengetahuan yang baik akan kebudayaan mereka. Bahkan hampir generasi muda Indonesia cenderung mengikuti budaya barat.

Sehubungan dengan kondisi tersebut, perlu menumbuhkan budaya literasi dengan ide kreatif sehingga kebudayaan dapat dikembangkan. Memanfaatkan kebudayaan yang dimiliki Indonesia adalah salah satu cara untuk tetap aktif membaca dan menulis. Banyak hal yang dapat dikembangkan sehingga pendidik ataupun peserta didik dapat memanfaatkan hal ini sebagai upaya menjaga budaya literasi.

Minangkabau sebagai suku masyarakat di Sumatera Barat memiliki kekayaan budaya, misalnya tari-tari tradisional. Akan tetapi, tidak semua orang memahami filosofi tarian tersebut. Bagi orang Minangkabau, segala hal yang disampaikan meskipun lewat tari dan musik memiliki makna dan cerita. Hal tersebutlah yang penting untuk dijaga dan dilestarikan lewat budaya literasi sehingga kearifan lokal budaya Indonesia dapat diperkenalkan kepada generasi bangsa kelak. 


\subsection{Rumusan Masalah}

Berdasarkan latar berlakang masalah di atas, dapat dirumuskan masalah sebagai berikut. (a) Bagaimanakah pemanfaatan teori dekonstruksi sebagai upaya meningkatkan budaya literasi? (b) Bagaimanakah dekonstruksi cerita asal usul tari tradisional minangkabau menjadi karya sastra berbasis kebudayaan lokal?

\subsection{Tujuan Penulisan}

Berdasarkan rumusan masalah di atas, tujuan penulisan makalah ini adalah sebagai berikut. (a) Menjelaskan pemanfaatan teori dekonstruksi sebagai upaya meningkatkan budaya literasi. (b) Menjaslakan dekonstruksi cerita asal usul tari tradisional minangkabau menjadi karya sastra berbasis kebudayaan lokal.

\section{Pembahasan}

\subsection{Pemanfaatan Teori Dekonstruksi sebagai Upaya Meningkatkan Budaya Literasi}

Dekonstruksi dikemukakan oleh Jacques Derrida, seorang filsuf Prancis yang lahir di Aljazair pada tahun 1930. Awalnya, dekonstruksi didefinisikan sebagai cara atau metode membaca teks. Secara leksikal prefiks 'de' berarti penurunan, pengurangan, penokohan, penolakan. Jadi, dekonstruksi dapat diartikan sebagai cara-cara pengurangan terhadap konstruksi, yaitu gagasan.

Menurut Al-fayyadl (2011:232), dekonstruksi adalah testimoni terbuka kepada mereka yang kalah, mereka yang terpinggirkan oleh stabilitas rezim bernama pengarang. Maka, sebuah dekonstruksi adalah gerak perjalanan menuju hidup itu sendiri. Dari sumber lain, dekonstruksi dikatakan sebagai sebuah metode pembacaan teks sehingga setiap teks selalu hadir anggapan-anggapan yang dianggap absolut. Padahal, setiap anggapan selalu kontekstual: anggapan selalu hadir sebagai konstruksi sosial yang menyejarah. Dengan demikian, anggapan-anggapan tersebut hadir sebagai jejak yang bisa dirunut pembentukannya dalam sejarah.

Sementara itu, menurut Sarup (2008:49), dekonstruksi Derrida adalah sebuah metode membaca teks secara sangat cermat hingga pembedaan konseptual hasil ciptaan penulis yang menjadi landasan teks tersebut terlihat tidak konsisten dan pradoks dalam menggunakan konsep-konsepnya dalam teks secara keseluruhan. Oleh karena itu, cara baca Derrida atas teks-teks filosofis adalah cara yang hendak melacak struktur dan strategi pembentukan makna di balik tiap teks. Derrida meyakini di balik teks filosofis bukanlah kekosangan, melainkan sebuah teks lain.

Sehubungan dengan konsep dekonstruksi di atas yaitu kehadiran dekonstruksi telah memungkinkan sebuah teks memiliki multi makna. Zulfadhli (2009:133) menambahkan dekonstruksionis menganggap bahwa bahasa teks bersifat logis dan konsisten. Teks tidak dibatasi maknanya. Misalnya, sebuah tema besar bahwa kejahatan 
akan terkalahkan dengan kebaikan dalam paham dekonstruksi hal ini tidak selalu dibenarkan, sastra dapat saja membalik atau mengubah tema besar itu menjadi tema baru.

Konsep itulah yang dianggap relevan dengan budaya literasi yang perlu ditingkatkan. Ali (2014) menyatakan bahwa secara sederhana literasi adalah sebuah kemampuan membaca dan menulis, tetapi saat ini literasi sudah memiliki arti yang luas. Seseorang dikatakan literat jika ia sudah bisa memahami sesuatu karena membaca informasi yang tepat dan melakukan sesuatu berdasarkan pemahamannya terhadap isi bacaan.

Ali (2014) pun menyatakan sebuah paradigma pentingnya literasi, yaitu penguasaan literasi dalam segala aspek kehidupan merupakan tulang punggung kemajuan peradaban suatu bangsa. Oleh karena itu, budaya literasi harus ditanamkan sejak dini agar anak bisa mengenal bahan bacaan dan menguasai dunia tulis-menulis. Dalam tulisannya, Ali (2014) pun menyimpulkan tentang perlunya rekaya literasi adalah suatu jalan menuju pada suatu perubahan dan peningkatan literasi anak bangsa dengan metode dan teknik pengajaran literasi yang mencerasakan.

Gagasan yang dikemukan oleh Ali merupakan sebuah upaya agar Indonesia tidak bertahan pada peringkat dua terbawah dari 30 negara berdasarkan data IAEA. Gagasan ini dianggap relevan dengan paham dekonstruksi yang dapat digunakan oleh pengajar atau pemerhati pendidikan, penulis, dan pelajar sehingga dapat memahami bacaan dengan baik serta memiliki kemampuan tulis menulis yang lebih baik pula.

\subsection{Dekonstruksi Cerita Asal Usul Tari Tradisional Minangkabau menjadi Karya Sastra Berbasis Kebudayaan Lokal}

Sehubungan dengan pembahasan pertama tersebut, bagian ini merupakan sebuah contoh gagasan pemanfaatan teori dekonstruksi untuk menciptakan karya sastra berbasis kebudayaan lokal. Gagasan ini menawarkan pemanfaatan cerita asal usul tari tradisional Minangkabau yang mengandung nilai kebudayaan lokal. Cerita asal usul tari tradisional dapat didekonstruksi menjadi berbagai cerita baru sehingga dapat memberikan bacaan yang sesuai dengan perkembangan zaman dan menyuguhkan nilai filosofis yang bermanfaat untuk pembentukan jiwa nasionalis bagi generasi muda.

Salah satu tari tradisional Minangkabau yang dapat dikembangkan menjadi karya sastra baru adalah Tari Piring. Secara singkat cerita asal usul Tari Piring dapat dikutip sebagi berikut.

Pada mulanya, kegunaan tari piring di daerah minangkabau, belum seperti kegunaan pada saat ini, yang dimana pada awalnya kegunaan tari piring ini digunakan oleh minangkabau pada saat musim panen tiba, yang dimana tari piring ini digunakan oleh masayarakat Minangkabau pada saat itu bertujuan untuk memberikan ucapan syukur kepada masyarakat setempat kepada dewadewa setelah mendapatkan hasil panen yang melimpah ruah. Ritual dilakukan 
dengan membawa sesaji dalam bentuk makanan yang kemudian diletakkan di dalam piring sembari melangkah dengan gerakan yang dinamis. Tetapi setelah datangnya agama islam di Minangkabau Tari Piring tidak lagi untuk persembahan para dewa tapi ditujukan bagi majlis-majlis keramaian yang dihadiri oleh para raja atau para pembesar negeri, Tari Piring juga dipakai dalam acara keramaian lain misalnya seperti pada acara pesta perkawinan. (Dikutip serperlunya: http://www.portalsejarah.com/sejarah-asal-usul-tari-piring-sertaperkembangannya.html)

Kutipan cerita di atas merupakan sebuah asal asul Tari Piring yang selama ini hanya dikenal keunikan gerakan tari dan penari-penarinya. Keberadaan cerita tersebut tentunya belum banyak yang mengetahui karena tidak semua orang berminat mencari tahu asal usul sebuah kebudayaan yang dimiliki bangsa. Mendekonstruksi cerita tersebut menjadi sebuah cerita baru dapat menjadi bahan bacaan yang menarik bagi anak bahkan sejak anak sedini mungkin. Pengenalan bahan bacaan yang berbasis kebudayaan dianggap juga akan mampu membentuk karakter anak sebagai anak yang mengenal budaya bangsanya. Selanjutnya, budaya literasi dianggap akan dapat dilanjutkan dengan adanya kegiatan penulisan baru berdasarkan teks sebelumnya yang telah dibaca dengan mendalam.

\section{Penutup}

Berdasarkan pembahasan pada bagian sebelumnya, dapat disimpulkan dua hal sebagai berikut. (1) teori dekonstruksi dapat dimanfaatkan sebagai upaya meningkatkan budaya literasi, yaitu melakukan rekaya literasi lewat dekonstruksi teks melalui pembacaan yang mendalam sehingga mengetahui adanya multi makna dibalik setiap teks. (2) Dekonstruksi cerita asal usul tari tradisional Minangkabau menjadi karya sastra berbasis kebudayaan lokal merupakan sebuah contoh pemanfaatan teori dekonstruksi untuk meningkatkan budaya literasi. Sebuah dekonstruksi dianggap dapat menjaga nilainilai filosofi yang terkandung dalam kebudayaan, misalnya tari tradisional.

\section{Daftar Pustaka}

Al-Fayyadl, Muhammad. (2011). Derrida. Yogyakarta: Lkis.

Ali, Haidar Muhammad. (2014). "Litarasi Sebagai Budaya Mencerdasakan Bangsa”. (Online) https://haidarism.wordpress.com/2014/02/18/literasi-sebagai-budayamencerdaskan-bangsa/, diunduh 8 Juli 2016.

http://www.portalsejarah.com/sejarah-asal-usul-tari-piring-serta-perkembangannya.html, diunduh 8 Juli 2016.

Sarup, Madan. (2008). Panduan Pengantara untuk Memahamai Postrukturalisme \& Posmodernisme (Terjemahaman Medhy Aginta Hidayat). Yogyakarta: Jalasutra. 
Zulfadhli. (2014). "Dekonstruksi dalam Cerpen Malin Kundang, Ibunya Durhaka Karya A.A. Navis". Jurnal Bahasa dan Seni, Vol, 10, No, 2, Tahun 2009, hlm. 132137.

\section{Biodata Penulis}

Nama : Yosi Wulandari

Afiliasi $\quad$ : Universitas Ahmad Dahlan, Prodi Pendidikan Bahasa dan Sastra Indonesia

Jalan Pramuka, No. 42, Umbulharjo, Yogyakarta

Nomor Telepon : 081363911151

Pos-el ～: yosi.wulandari@pbsi.uad.ac.id 